Winter 2011

\title{
The Power of Definition: Brazil's Contribution to Universal Concepts of Indigeneity
}

Jan Hoffman French

University of Richmond

Follow this and additional works at: https://www.repository.law.indiana.edu/ijgls

Part of the International Law Commons

\section{Recommended Citation}

French, Jan Hoffman (2011) "The Power of Definition: Brazil's Contribution to Universal Concepts of Indigeneity," Indiana Journal of Global Legal Studies: Vol. 18 : Iss. 1 , Article 11.

Available at: https://www.repository.law.indiana.edu/ijgls/vol18/iss1/11

This Symposium is brought to you for free and open access by the Law School Journals at Digital Repository @ Maurer Law. It has been accepted for inclusion in Indiana Journal of Global Legal Studies by an authorized editor of Digital Repository @ Maurer Law. For more information, please contact rvaughan@indiana.edu.

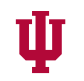

JEROME HALL LAW LIBRARY INDIANA UNIVERSITY Maurer School of Law
Blooming ton 


\title{
The Power of Definition: Brazil's Contribution to Universal Concepts of Indigeneity
}

\author{
JAN HOFFMAN FRENCH*
}

\begin{abstract}
This article builds on discussions about the potential benefits and difficulties with developing a universal definition of indigenous peoples. It explores the spaces made available for theorizing indigeneity by the lack of a definition in the United Nations Declaration on the Rights of Indigenous Peoples, adopted in 2007. Specifically, this article addresses the challenge presented by the diversity of groups claiming indigenous status in Brazil. To what extent do distinct cosmologies and languages that mark Amazonian Indians as unquestionably indigenous affect newly recognized tribes in the rest of Brazil who share none of the indicia of authenticity? This article theorizes how to situate these newly recognized tribes within the context of the Declaration and addresses what the Brazilian experience has to offer in providing openings for claims that might have been made through alternative means, such as land reform and international cultural heritage rights.
\end{abstract}

\section{INTRODUCTION}

In my recent book, Legalizing Identities: Becoming Black or Indian in Brazil's Northeast, ${ }^{1}$ I analyzed the process by which groups of black

* Ph.D., 2003, Duke University, Department of Cultural Anthropology; J.D., 1981, University of Connecticut School of Law; B.A., 1975, Temple University. Jan Hoffman French is Assistant Professor of Anthropology at the University of Richmond. In addition to her recent book, she has published articles in the American Anthropologist, American Ethnologist, and the Americas, as well as numerous book chapters. French has held postdoctoral fellowships at the Kellogg Institute for International Studies, Northwestern University, and the University of Maryland, College Park. Before becoming an anthropologist, she practiced law. I would like to thank Alfred Aman, Jr., Shane Greene, Bradley Levinson, Beverly Stoeltje, and Christiana Ochoa for organizing the conference at which this article was first presented and for encouraging its publication.

Indiana Journal of Global Legal Studies Vol. 18 \#1 (Winter 2011)

(C) Indiana University Maurer School of Law 
rural workers were reconstituting themselves in relation to their strand of indigenous ancestry and were being recognized as Indians by the Brazilian government. ${ }^{2}$ Brazil is known as a place where indigenous peoples are exemplified by non-European languages, cosmologies, rituals, dress, and preconquest histories. However, over the past few decades, Brazil has been pioneering a broadening of the concept of indigenous peoples to include people previously assumed to be fully assimilated into the nation's general population. In fact, over the past thirty years, the Brazilian government has recognized more than forty new "tribes" in the Northeast region alone. ${ }^{3}$ During that same period, many other presumably assimilated people demanded and received both recognition and access to land as Indians in other parts of eastern Brazil, including the state of Rio de Janeiro. ${ }^{4}$

These new Indians exist within a larger, flexible, international context of indigenous peoples made available for theorizing indigeneity by the lack of definition in the United Nations Declaration on the Rights of Indigenous Peoples (the Declaration). ${ }^{5}$ To what extent do distinct cosmologies and languages that unquestionably mark Amazonian groups, such as the Wari, Xavante, or Kayapo, as indigenous affect newly recognized tribes in the rest of Brazil who share none of these indicia of authenticity? Is it conceptually defensible from both an ethical and legal perspective of justice to include in a single category both people who have a clear claim to "difference" and have struggled for generations to gain even limited political autonomy, and those who have just recently discovered their claim to indigeneity under an expansive view of indigenous peoples?

This article is divided into three sections. The first explains the construction of global indigenous identity through the extensive process

1. JaN HOFFMAN FRENCH, LEgalizing IDENTITIES: BECOMING BlaCK OR INDIAN IN BRAZIL'S NORTHEAST (2009).

2. "[T]n Brazil [the term] Indian has gone through phases of denigration and of regeneration. The indigenous movement of the $1970 \mathrm{~s}$ and $1980 \mathrm{~s}$ reappropriated the term and infused it with a substantial dose of political agency." ALCIDA RITA RAMOS, INDIGENISM: ETHNIC POLITICS IN BRAZIL 6 (1998). In fact, the use of the term has come to be considered a "dynamic element] of struggle." MARía ElENA GarCía, MAKING Indigenous Citizens: IDENTITY, DEVEloPMENT, AND MULTICUltural ACTIVISM IN PERU 27 (2005).

3. Joāo Pacheco de Oliveira Filho, atlas das terras Indigenas do Nordeste (1993); Stephen G. Perz, et al., Contributions of Racial-Ethnic Reclassification and Demographic Processes to Indigenous Population Resurgence: The Case of Brazil, 43 LATIN AM. RES. REV. 7, 27 (2008).

4. See generally JONATHAN W. WARREN, RACIAL REVOlUTIONS: ANTIRACISM AND INDIAN RESURGENCE IN BRAZIL (2001) (analyzing the processes of racial formation among "posttraditional Indians" at various sites in eastern Brazil).

5. Declaration on the Rights of Indigenous Peoples, G.A. Res. 61/295, U.N. Doc. A/RES/61/295 (Sept. 13, 2007) [hereinafter Declaration]. 
of negotiating and adopting the Declaration. Due to insurmountable difficulties in reaching agreement, a definition of indigenous peoples was simply excluded from the Declaration. What remains is an openended concept to be interpreted contextually. This article takes the view that a definition of indigenous peoples in the Declaration would be counterproductive, thus supporting the decision made by the deliberating body. In the second section, I address the challenge that the failure to agree on a legal definition of indigenous peoples poses to anthropology, a field superbly positioned to analyze and assist in conceptualizing meanings of indigeneity. Therefore, it is argued that discussions of international legal definitions of indigeneity should be made integral to anthropological perspectives. The third section uses the Brazilian example to suggest both a temporal and a spatial construction of diaspora as a justification for a broadened perspective on indigeneity worldwide. In the Brazilian case, the definition of Indian enacted in 1973 performed the same function as the exclusion of a definition of indigenous peoples in the Declaration on an international level, an opening up of the criteria for claiming indigenous rights.

\section{GLOBAL INDIGENOUS IDENTITY CONSTRUCTION}

After over two decades of meetings and negotiations, the Declaration was adopted by the 61st General Assembly of the United Nations on September 13, 2007, establishing

a universal framework of minimum standards for the survival, dignity, well-being and rights of the world's indigenous peoples. The Declaration addresses both individual and collective rights; cultural rights and identity; rights to education, health, employment, language, and others. It outlaws discrimination against indigenous peoples and promotes their full and effective participation in all matters that concern them. It also ensures their right to remain distinct and to pursue their own priorities in economic, social and cultural development. The Declaration explicitly encourages harmonious and cooperative relations between States and indigenous peoples. ${ }^{6}$

6. U.N. High Comm'r for Human Rights, Declaration on the Rights of Indigenous Peoples, http://www2.ohchr.org/english/issues/indigenous/declaration.htm (last visited Oct. 17, 2010). 
Although the Declaration is not a legally binding instrument, it is declaratory of customary international law. ${ }^{7}$ Even while the Declaration was in draft form, national courts began citing it in support of indigenous rights. ${ }^{8}$ After twenty-three years of negotiation, the Declaration was adopted by a vote of $143-4$ with eleven abstentions. ${ }^{9}$ According to a U.N. press release, "countries voting against the Declaration (Australia, Canada, New Zealand, and the United States) said they could not support it because of concerns over provisions on self-determination, land and resources rights, and, among others, language giving indigenous peoples a right of veto over national legislation and State management of resources." 10 The twentythree year delay in adoption is attributable to two sticking points: the draft Declaration asserts the importance of self-determination of indigenous peoples, ${ }^{11}$ and the term "indigenous peoples" is not defined. The adoption of the Declaration was delayed for an additional year as a result of objections and proposed amendments by a group of African states. ${ }^{12}$ Their fundamental objections were the absence of a definition of indigenous peoples and the possible encouragement of internal ethnic groups to assert a right to self-determination and to secede from the state. ${ }^{13}$

7. Paul Oldham \& Miriam Anne Frank, We the Peoples...? The United Nations Declaration on the Rights of Indigenous Peoples, 24 ANTHROPology TODAY 5, 5 (Apr. 2008).

8. See Erica-Irene A. Daes, An Overview of the History of Indigenous Peoples: SelfDetermination and the United Nations, 21 CAMBrIDGE REV. OF INT'L AFF. 7, 23 (2008) (citing (Consol.) re Maya Land Rights, Claim Nos. 171-72, ๆ 131 (Sup. Ct. 2007) (Belize), available at http://www.belizelaw.org/supreme_court/judge_list/civil_judge_2007.html) (follow "Supreme Court Claims Nos. 171 and 172 of 2007 (Consolidated) re Maya land rights" hyperlink).

9. Australia, Canada, New Zealand, and the United States voted against the Declaration. Azerbaijan, Bangladesh, Bhutan, Burundi, Colombia, Georgia, Kenya, Nigeria, Russian Federation, Samoa, and Ukraine abstained. Press Release, General Assembly, General Assembly Adopts Declaration on Rights of Indigenous Peoples; 'Major Step Forward' Towards Human Rights for All, Says President, U.N. Press Release GA/10612 (Sept. 13, 2007) [hereinafter G.A. Press Release].

10. Id.

11. See generally Daes, supra note 8 , at 8 (describing the author's (who was the principal drafter of the Declaration) belief that there is an intrinsic link between selfidentification and self-determination); Andrea Muehlebach, What Self in SelfDetermination? Notes from the Frontiers of Transnational Indigenous Activism, 10 IDENTITIES: GLOBAL STUD. CULTURE \& POWER 241 (2003) (describing how transnational indigenous activists are shaping the development of the concept of self-determination) [hereinafter Muehlebach, Self-Determination].

12. The three African states that delayed the final vote were Botswana, Namibia, and Nigeria.

13. See Draft Aide Memoire, African Group, United Nations Declaration on the Rights of Indigenous People paras. 2.0-5.0 (Nov. 9, 2006), available at http://www.ipacc.org. za/uploads/docs/Africanaidememoire.pdf. After further negotiations, all of the African 
The International Work Group for Indigenous Affairs (IWGIA), a nongovernmental organization, estimates that "[t]here are over 370 million indigenous people in Africa, the Americas, Asia, Europe and the Pacific." " However, the concept of indigenous peoples encoded in the Declaration is left undefined. ${ }^{15}$ In the absence of an agreement on a definition, the United Nations Working Group on Indigenous Peoples (WGIP) ${ }^{16}$ and the inter-sessional Working Group on the draft Declaration ${ }^{17}$ asserted that an explicit definition of indigenous peoples would reduce the effectiveness of the Declaration, which should, it was argued, hinge primarily on self-identification. For example, most definitions that were considered and rejected required that people show direct descent from an identifiable group of people inhabiting the same place as the group claiming indigenous rights before it was colonized. It was feared that this requirement of "firstness," would exclude groups in Africa and Asia. Another problematic requirement was one in which cultural practices or a distinct language must be retained from the distant past. This would have excluded groups that were forced to

countries voted in favor of the Declaration; Burundi, Kenya, and Nigeria abstained. G.A. Press Release, supra note 9.

14. Int'l Work Grp. for Indigenous Aff. [IWGIA], Declaration on the Rights of Indigenous Peoples, http://www.iwgia.org/sw248.asp (last visited Oct.17, 2010). Their inclusion criteria can also be found on their website. IWGIA, Identification of Indigenous Peoples: Indigenous Peoples-Who are They?, http://www.iwgia.org/sw641.asp (last visited Oct. 17, 2010). The International Labour Organization confirms that "[i]ndigenous and tribal peoples constitute at least 5,000 distinct peoples with a population of more than 370 million, living in 70 different countries." ILO, Nicaragua Ratifies ILO Indigenous and Tribal Peoples Convention, 1989 (No. 169) (Aug. 30, 2010), http://www.ilocarib.org. tt/portal/index.php?option=com_content\&task=view\&id=1411\&Itemid=368.

15. See Dep't of Econ. \& Soc. Aff., Secretariat of the Permanent Forum on Indigenous Issues, State of the World's Indigenous Peoples, at 4-7, U.N. Doc. ST/ESA/328, U.N. Sales No. 09.VI.13 (2009) (explaining the decision to exclude a definition).

16. The United Nations Economic and Social Council established the WGIP as a "transnational locality" (in the sense that a new political space was created) in 1982. See Andrea Muehlebach, 'Making Place' at the United Nations: Indigenous Cultural Politics at the U.N. Working Group on Indigenous Populations, 16 CUltURAL ANTHROPOLOGY 415, 415-16 (2001) ("It is the only global institution at which indigenous identity has for years been discussed.") [hereinafter Muehlebach, Cultural Politics].

17. In 1995, the United Nations Commission on Human Rights established the intersessional Working Group with "the sole purpose of elaborating a draft declaration on the rights of indigenous peoples." Office of the U.N. High Comm'r for Human Rights, Working Group on the Draft Declaration on the Rights of Indigenous Peoples, http://www2.ohchr.org/english/issues/indigenous/groups/groups-02.htm (last visited Oct. 22, 2010). That same year, the General Assembly decided that the "United Nations Voluntary Fund for Indigenous Populations should also be used to assist representatives of indigenous communities and organizations authorized to participate in the deliberations of the Working Group on the draft declaration." Id. 
assimilate but are now dedicated to reconstituting group identity as indigenous. ${ }^{18}$

Most discussions of the Declaration begin with the working definition of indigenous proposed by U.N. Special Rapporteur José Martínez-Cobo in his Study of the Problem of Discrimination against Indigenous Populations, which states:

Indigenous communities, peoples and nations are those which, having a historical continuity with pre-invasion and pre-colonial societies that developed on their territories, consider themselves distinct from other sectors of the societies now prevailing in those territories, or parts of them. They form at present nondominant sectors of society and are determined to preserve, develop and transmit to future generations their ancestral territories, and their ethnic identity, as the basis of their continued existence as peoples, in accordance with their own cultural patterns, social institutions and legal systems. ${ }^{19}$

The WGIP bore this definition in mind as negotiations proceeded but did not adopt it. ${ }^{20}$ Moreover, although there is a definitional provision in the International Labour Organization (ILO) International Indigenous and Tribal Peoples Convention 169 of 1989, which has been ratified by twenty-one countries, ${ }^{21}$ the indigenous negotiators insisted

18. For example, the Mashpee Indians in Massachusetts were only recently granted federal recognition after decades of appealing a 1980s court decision that found they had not proven historical continuity or distinct cultural practices traceable to specific ancestors from the same place. See JAMES ClIFFORD, Identity in Mashpee, in THE Predicament of Culture: Twentieth-Century EThNography, Literature, and ART 277 (1988). See also Andrew Ryan, Mashpee Tribe Wins Federal Recognition, Bos. GLOBE, Feb. 16, 2007 at B8 (for information on the 2007 federal recognition).

19. Special Rapporteur on the Study of the Problem of Discrimination Against Indigenous Populations, Final Rep. on the Study of the Problem of Discrimination Against Indigenous Populations, para. 379, Comm. on Human Rights, U.N. Doc. E/CN.4/Sub.2/1983/21/Add.8 (Sept. 30, 1983) (by José R. Martínez Cobo). According to Erica-Irene Daes, this definition has been unofficially used in certain cases. Special Rapporteur on the Discrimination Against Indigenous Peoples, Final Rep. on the Protection of the Heritage of Indigenous Peoples, para. 18, Comm. on Human Rights, U.N. Doc. E/CN.4/Sub.2/1995/26 (June 21, 1995) (by Erica-Irene Daes).

20. PATRICK ThoRNBERRY, INDIgenous PEOPLES AND HUMAN RightS 33 (2002).

21. In 1989, ILO Convention No. 169 was adopted with the following provision in Article 1:

1. This Convention applies to: 
that anything short of self-identification would not provide the flexibility needed for an inclusive and self-determining process of recognition.

Components of both the Martínez-Cobo and ILO definitions were problematic from the perspective of self-identification. For example, in the Martínez-Cobo definition, the phrase "historical continuity with preinvasion and pre-colonial societies that developed on their territories" presented the problem of excluding peoples living in nonsettler societies, along with displaced and diasporic indigenous peoples. ${ }^{22}$ Another example is the 2006 U.S. proposal to the Working Group on the Draft Declaration, which illustrates just how limiting the effort to pin down a definition can be. The U.S. proposal was rejected by the drafters, but it would have required state recognition prior to U.N. recognition:

\begin{abstract}
(a) tribal peoples in independent countries whose social, cultural and economic conditions distinguish them from other sections of the national community, and whose status is regulated wholly or partially by their own customs or traditions or by special laws or regulations; (b) peoples in independent countries who are regarded as indigenous on account of their descent from the populations which inhabited the country, or a geographical region to which the country belongs, at the time of conquest or colonization or the establishment of present state boundaries and who, irrespective of their legal status, retain some or all of their own social, economic, cultural and political institutions.

2. Self-identification as indigenous or tribal shall be regarded as a fundamental criterion for determining the groups to which the provisions of this Convention apply.
\end{abstract}

ILO: Convention Concerning Indigenous and Tribal Peoples in Independent Countries art. 1, paras. 1-2, June 27, 1989, 28 I.L.M. 1382 (entered into force Sept. 5, 1991). Nicaragua is the most recent country to ratify the Convention, bringing the number to 21 . ILO, Nicaragua Ratifies ILO Indigenous and Tribal Peoples Convention, 1989 (No. 169) (Aug. 30, 2010), www.ILO.oRG, http://www.ilocarib.org.tt/portal/index.php?option=com_content\& task=view\&id $=1411 \&$ Itemid $=368$.

22. Martínez-Cobo, supra note 19, at para. 379; see also James Clifford, Varieties of Indigenous Experience: Diasporas, Homelands, Sovereignties, in INDIGENOUS EXPERIENCE TODAY 197 (Marisol de la Cadena \& Orin Starn eds., 2007) (exploring the diversity of claims to indigeneity and arguing for their legitimacy). In this article, I am not directly addressing the issue of connection to land as a defining factor for indigeneity in the Declaration. The tension between a definition that focuses on social and cultural identity and one that is primarily about territory is reflected in the Declaration. Right to land "which [indigenous peoples] have traditionally owned, occupied or otherwise used" is enshrined in Article 26, along with a directive to States to "give legal recognition and protection to these lands." Declaration, supra note 5, art. 26, paras. 1, 3. However, claim to land or connection to territory is not a prerequisite for coverage by the Declaration. For example, "historic injustices" are seen as resulting from "inter alia, their colonization and dispossession of their lands, territories and resources." Id. annex (emphasis added). Cultural protection and self-determination are accorded more space in the Declaration than land issues. 
Indigenous peoples have the right to be recognized as such by the State through a transparent and reasonable process. When recognizing indigenous peoples States should include a variety of factors, including, but not limited to ... whether the group ... . self-identifies as indigenous; . . . is comprised of descendants of persons who inhabited a geographic area prior to the sovereignty of the State; . . . historically had been sovereign; . . . maintains a distinct community and aspects of governmental structure; . . . has a cultural affinity with a particular area of land or territories; . . . has distinct objective characteristics such as language, religion, culture; and, ... has been historically regarded and treated as indigenous by the State. ${ }^{23}$

Evident from this proposal is the influence of the U.S. Bureau of Indian Affairs requirements that have restricted federal recognition for many groups over the years. ${ }^{24}$ Such a definition, it was felt by the drafters, would have been impractical in a transnational context. The indigenous participants viewed the lack of a definition of indigenous peoples as impractical and equivalent to a refusal to use the "language understood by those wielding power." 25 Indigenous representatives in WGIP meetings in the 1990s expressed the view that unless a "law reaches out to the varieties of human existence," it should be considered deficient. ${ }^{26}$ They also asserted that for a law to be morally valid, "it must have the consent of . . . those affected" 27 by its provisions.

Self-identification, although fundamental to the recognition of indigenous peoples on the international level, is not the only criterion important to indigenous representatives, as "[i]ndigenous peoples are

23. Chairperson-Rapporteur on the ESCOR, Comm'n H.R., Report of the Working Group on the Draft United Nations Declaration on the Rights of Indigenous Peoples, 27-29, U.N. Doc. E/CN.4/2006/79 (Mar. 22, 2006) (by Luis-Enrique Chávez). In June, the Obama administration announced that the United States would review its position on the Declaration. Press Release, Office of the Spokesman, U.S. Review of the U.N. Declaration on the Rights of Indigenous Peoples (June 4, 2010), http://www.state.gov/r/pa/prs/ps/ 2010/06/142662.htm.

24. E.g., Clifford, supra note 18 (describing the history of Massachusetts' Mashpee Indians and their 1976 lawsuit claim for land, which was ultimately unsuccessful because they did not meet the "tribal" criteria).

25. Justin Kenrick \& Jerome Lewis, Indigenous Peoples' Rights and the Politics of the Term 'Indigenous', 20 ANTHROPOLOGY TODAY 4, 9 (Apr. 2004).

26. THORNBERRY, supra note 20, at 10 (2002) (quoting ANDREW LINKLATER, THE Transformation of POLITICAL COMMUNity: ETHical Foundations of THE PostWESTPHALIAN ERA 96 (1998)).

27. Id. 
not only those who say they are indigenous but also those who are accepted by a global network of nations and communities with similar claims and sources of recognition." 28 Therefore, both self-identification and other-identification are critical to public recognition. There is little doubt that the decision to leave the concept open and flexible has contributed to the expansion of the number of groups who self-identify and who are recognized as indigenous by the United Nations and other international bodies. It has also encouraged the growing identification of indigenous activists, representatives, and intellectuals with a global indigenous identity that has influenced the actions of international and state entities. ${ }^{29}$ Such a global indigenous identity allows groups to "gain voice through cross-national connections that empower their approach to national dilemmas." 30 Moreover, this global indigenous identity does not adhere to international actors alone, but is crucial to selfidentification by local peoples in settings ranging from the Sami people in northern Europe to the San people in southern Africa. ${ }^{31}$

28. Ronald Niezen, The ORIGINS OF Indigenism: Human Rights ANd the PoltTics OF IDENTITY 22, $227 \mathrm{n} .21$ (2003) (reporting a definition proposed by indigenous delegates). In the United States, the assumption of solidarity among indigenous peoples is not a given. For example, the leadership of the Eastern Band of Cherokee opposes federal recognition of the Lumbee Indian Tribe in North Carolina. See, e.g., Lumbees Clash with Cherokee at Senate Hearing, INDIANZ.COM, (July 13, 2006), http://64.38.12.138/News/ 2006/014928.asp.; Senators Seek Lumbee Recognition, NEWSOBSERVER.COM, (Oct. 10, 2009, 2:08 PM), http://www.newsobserver.com/2009/10/01/121289/senators-seek-lumbee recognition.html\#storylink=misearch.

29. See, e.g., NIEZEN, supra note 28 (discussing the indigenism movement as a new global political entity and providing a history of the movement's relationships with states and international bodies); Marcus Colchester, Indigenous Rights and the Collective Conscious, 18 ANTHRopology Today, Feb. 2002, at 1, 2-3; Daes, supra note 8, at 8-11; Kenrick \& Lewis, supra note 25, 4-9; Benedict Kingsbury, "Indigenous Peoples" in International Law: A Constructivist Approach to the Asian Controversy, 92 AM. J. INT'L L. 414, 414-15, 417-26 (1998); Muehlebach, Self-Determination, supra note 11, at 244-46, 254-56, 261-63; Muehlebach, Cultural Politics, supra note 16 (describing the WGIP's role in the transnational indigenous movement); Oldham \& Frank, supra note 7 (giving a detailed account of the Declaration's adoption and the history of its drafting and status as a resolution); Viniyanka Prasad, The UN Declaration on the Rights of Indigenous Peoples: A Flexible Approach to Addressing the Unique Needs of Varying Populations, 9 CHI. J. INT'L L. 297, 311-15 (2009). But see Michaela Pelican, Complexities of Indigeneity and Autochthony: An African Example, 36 AM. ETHNOLOGIST 52 (2009) (describing several examples of how countries have ignored global indigenism or used it to harm those the movement intended to protect).

30. Anna Tsing, Indigenous Voice, in INDIGENOUS EXPERIENCE TODAY 33, 57 (Marisol de la Cadena \& Orin Starn eds., 2007).

31. See Dorothy L. Hodgson, Introduction: Comparative Perspectives on the Indigenous Rights Movement in Africa and the Americas, 104 AM. ANTHROPOLOGIST 1037, 1039-40 (2002). 
The trend toward an expansive definition of indigenous peoples began well before the Declaration was adopted and is directly linked to the increased participation of representatives from Africa and Asia (places that, until recently, were excluded from consideration as not having indigenous groups). ${ }^{32}$ As standard assumptions moved away from the notion that the existence of indigenous peoples were confined to settler societies, such as those in the Western Hemisphere, Australia, and New Zealand, an expanded perspective on the definition of indigeneity began to take hold in U.N. deliberations. The involvement of indigenous participants in deliberations and negotiations leading up to the Declaration's adoption was unprecedented. ${ }^{33}$ In 1982 , when the WGIP was established, only thirty representatives were present. In 1999, nearly one thousand participants attended the WGIP meeting, creating a site of "discursive density." 34

The Global Indigenous Peoples' Caucus, consisting of the group of indigenous delegates present at the WGIP meetings, would meet to discuss their positions on the issues at stake through intense debate and consensus decision making. ${ }^{35}$ Erica-Irene Daes, Chairperson and Special Rapporteur of the WGIP from its founding until 2001 and principal drafter of the Declaration, explains that indigenous peoples were not part of original state building. ${ }^{36}$ This reminder makes the indigenous representation at every stage during the twenty-three year period of drafting, debating, and redrafting the Declaration even more impressive. Such participation contributed to the constitution of a supranational indigenous identification. Patrick Thornberry, international law scholar and an observer at WGIP meetings, described

32. U.N. PERMANENT FORUM ON INDIGENOUS ISSUES, Trust Fund on Indigenous Issues Relating to the Second International Decade of the World's Indigenous People http://www.un.org/esa/socdev/unpfii/en/second_trustfund.html\#2009 (last visited Oct. 9, 2010). In May 2009, the United Nations Permanent Forum on Indigenous Issues, as advisor for projects for the Second International Decade of the World's Indigenous People, proposed to award grants to nineteen projects in Africa, Asia, Latin America and the Caribbean, Eurasia (a region covering Eastern Europe, the Russian Federation, Central Asia, and Transcaucasia), North America, and the Pacific.

33. See Daes, supra note 8, at 12-18; see also Muehlebach, Self-Determination, supra note 11 (discussing the increasingly visible presence of indigenous delegates in the international arena in a number of contexts); Oldham \& Frank, supra note 7, at 6-8.

34. Muehlebach Cultural Politics, supra note 16, at 415, 420.

35. E.g., Oldham \& Frank, supra note 7 (describing in detail the response of the Caucus to the African Group's Draft Aide-Memoire).

36. See Daes, supra note 8 , at 13 . State-building is a reference to the process by which a nation is transformed into a nation-state with an independent government and laws. In Hispanic America, for example, creoles (descendants of colonizing Spaniards) were the primary group involved in state-building in the nineteenth century. Indigenous populations were excluded from the state-building project. 
the meetings as "[a]rguments between government delegations and the indigenous [that] seemed interminable, their position statements incommensurable. But there was also a sense of something shifting, of ideas grinding their way through the morass of argument and rebuttal, storytelling and complaint." 37

While increased indigenous participation in the draft Declaration negotiations was crucial to its eventual adoption, there was also some concern that such participation was restricted to an upper echelon of indigenous delegates. Anthropologist Jonathan Friedman has argued the risk that class inequalities might be reinforced between delegates and the people at home whom they represent. ${ }^{38} \mathrm{He}$ refers to the internationally active indigenous delegates as part of a "global cocktail circuit." 39 Over a decade ago, when Friedman made this comment, it may have been appropriate to be suspicious of claims to a global indigenous identity, both as a top-down imposition and as a distraction from studying local cultural specificities. Today, it is necessary to rethink such cautionary reactions because indigeneity and indigenous rights are commonly accepted notions that affect localities around the world. Generally, an anthropological approach to indigeneity would emphasize the specificities of particular groups, paying less attention to the impact of events at an international level (see section III below). However, some anthropologists, such as Mary Louise Pratt, are beginning to take a different approach and are criticizing the established anthropological wisdom by asserting that it should no longer be a given that "perform[ing] the always legitimating scholarly gesture of presenting complicated truth against . . . reductive ideology" 40 is the only or best way to approach global indigenous identity. This still leaves the question of which foundational justifications for claims to indigenous rights are valid, particularly if self-identification has become the primary requirement on the international level. Once historical continuity, language and cultural practices, and blood quantum are no

37. ThORNBERRY, supra note 20, at 10. See generally Noel Castree, Differential Geographies: Place, Indigenous Rights and 'Local' Resources, 23 POL. GEOGRAPHY 133, 161 (2004) (exploring reasons why indigenous peoples should have the right "to make their own places rather than have them made for them.").

38. Jonathan Friedman, Indigenous Struggles and the Discreet Charm of the Bourgeoisie, in Places AND Politics IN AN AGE of Globalization 53, 64 (Roxann Prazniak \& Arif Dirlik eds., 2001).

39. Id.

40. Mary Louise Pratt, Afterword: Indigeneity Today, in INDIGENOUS EXPERIENCE TODAY 397, 400 (Marisol de la Cadena \& Orin Starn eds., 2007). 
longer required foundational justifications for the recognition of an indigenous people, it will be crucial to develop other justifications. ${ }^{41}$

More capacious definitional possibilities allow peoples claiming indigeneity, such as international agencies and national governments, to consider other morally powerful justifications for such claims. In The Moral Force of Indigenous Politics: Critical Liberalism and the Zapatistas, political scientist Courtney Jung provides an alternative analysis. ${ }^{42}$ She sees indigenous identity as a "political achievement," not as "an accident of birth" or a "spontaneous global reaction in defense of cultural preservation." 43 Jung proposes a theory of political identity formation according to which "indigenous people are partly constituted as a potential group because they occupy a common location of structural exclusion from the modern state, not because they possess a common language or culture." 44 Recognition as indigenous should flow not from a notion of existential identity, but rather from what the larger society and state has done to the group over time-how the group has been treated by state institutions and majority populations. ${ }^{45}$ However, such a structural location does not by itself produce an indigenous rights movement. The concept of indigenous rights must first "develop[] sufficient traction to orient, and to open the political space for, indigenous politics." 46 Echoing such a perspective, anthropologist Mary Louise Pratt has observed that indigeneity should be viewed "not as a condition but [as] a force," a "bundle of generative possibilities." 47 In my opinion, the political space referred to by Jung, together with Pratt's notion of a "force," are served by loosening definitional fetters and considering alternative justifications for indigenous self-identification and other-identification. ${ }^{48}$

41. There has been a certain fetishization of firstness or priority of settlement with regard to identification of indigeneity around the world. However, a claim to being first in a particular place can be a double-edged sword. Indigenous rights, based on a claim to priority, may be used by those who are structurally in a relatively powerful, and even exploitative, position. See Adam Kuper, The Return of the Native, 44 CURRENT ANTHROPOLOGY 389, 389 (2003).

42. Courtney Jung, The Moral Force of Indigenous Politics: Critical LIBERALISM AND THE ZAPATISTAS (2008) (analyzing the shift from peasant to indigenous politics by the Zapatistas in Mexico).

43. Id. at $11,20$.

44. Id. at 69 .

45. See id. at 33 .

46. Id. at 69 .

47. Pratt, supra note 40 , at 400,402 .

48. As one Zapatista activist who was at first reluctant to embrace indigenous identity indicated to Jung, "his concern was never an existential one . . . Instead, what he hoped was that indigenous identity would reconstitute the terms of struggle." JUNG, supra note 


\section{ANTHROPOLOGY AND INTERNATIONAL LAW}

Anthropologist Sally Engle Merry has written on the contributions anthropology has made, and can make, to understanding international law. 49 Merry's review of the literature has unearthed a number of contributions, particularly the component that shows how anthropological theory helps us understand "how international law is produced and how it works." 50 The inverse is also true. International legal definitional discussions, decisions, and contestations can greatly enhance anthropological thinking about indigeneity.

A number of anthropologists evaluating definitional issues surrounding the terms indigenous peoples and indigeneity have concluded that such terms are not useful anthropological concepts from an analytical perspective because they are too essentializing, too tied to the land, or too broadly conceived.51 However, those same scholars condescendingly agree that, although such terms are not adequate for anthropological analysis, they are useful as legal concepts, as tools for political persuasion, or as meaningful terms "for those who identify themselves as indigenous." 52 Some take a slippery slope approach, arguing that the use of the concepts will inevitably lead to ethnic strife, ${ }^{53}$ while others distinguish between indigenism (an internationalist endeavor) and ethnonationalism, which rests on myths

42 , at 78 . In other words, his reluctance was not based on his own conception of his personal identity, but stemmed from considerations of his political identity.

49. See Sally Engle Merry, Anthropology and International Law, 35 ANN. REv. ANTHROPOLOGY 99, 100 (2006).

50. Id. at 9. "[A]nthropological research plays a critical role in examining how international law works in practice, mapping the circulation of ideas and procedures as well as examining the array of small sites in which international law operates ...." Id. at 111.

51. See Kuper, supra note 41; Pelican, supra note 29, at 53.

52. Pelican, supra note 29, at 54; accord Alan Barnard, Kalahari Revisionism, Vienna and the 'Indigenous Peoples' Debate, 14 Soc. AnThropology 1, 7, 13 (2006). Pelican believes that "stripping the concept of 'indigenous peoples' of its original connotations of priority in time and historical continuity is debatable." Pelican, supra note 29, at 56. Pelican also discusses the relationship between Cameroon's Grassfielders and Mbororo people as an example; the latter, despite being relative newcomers "locally perceived as strangers or allogènes, qualify on the international level as indigenous peoples." Id. at 58. This leads me to raise the question of how much deference international agencies should give to local views (the United States' desire to impose its definitional requirements is instructive). But see John Bowen, Should We Have a Universal Concept of 'Indigenous Peoples' Rights? Ethnicity and Essentialism in the Twenty-First Century, 16 ANTHROPOLOGY TODAY 12 (2000) (proposing an intermediate and alternative two-level analysis for determining indigeneity from an anthropological perspective).

53. See Friedman, supra note 38 , at 397-99; Kuper, supra note 41, at 395; Pelican, supra note 29 , at 61 . 
of cultural purity and frequently involves movements that seek secession from the host nation-state. ${ }^{54}$

There is also a fear that encouraging collective indigenous rights might lead to abuses of individual human rights by a group uncontrolled by the state. This concern is often based on an assumed lack of democratic process in indigenous settings. However, indigenous groups are aware of concerns about potential abuses of individual rights and have begun to address this issue at an international level. The Manila Declaration of the International Conference on Conflict Resolution, Peace Building, Sustainable Development, and Indigenous Peoples, held in December 2000 with extensive indigenous participation, recognized justice as universal and acknowledged that a revitalization of traditions should not lead to oppression of women and children. ${ }^{55}$ Again, there is a risk of condescension in assuming that people who self-identify as indigenous are uninterested in or incapable of participating in a democratic process. ${ }^{56}$ There is no reason why international legal processes that call human rights violations into question cannot be applied to recognized indigenous groups.

In fact, anthropologists are increasingly arguing against the notion that collective rights are intrinsically dangerous. ${ }^{57}$ Moreover, the notion of "culture," as conceptualized by anthropologists, has shifted to an active process of self-making and production of identity. In the international indigenous rights context, a consensus is growing that such identity construction is central to "building global alliances to resist global processes of dispossession." 58 A number of legal scholars have begun to take the position that issues of representativeness and possible abuses of individual rights should neither be ignored nor

54. Noel Castree, Differential Geographies: Place, Indigenous Rights and 'Local' Resources, 23 POL. GEOGRAPHY 133, 152 (2004) (citing Ronald Niezen, Recognizing Indigenism: Canadian Unity and the International Movement of Indigenous Peoples, 42 COMP. STUD SOC'Y \& HIST. 119, 120 (2000)).

55. International Conference on Conflict Resolution, Peace Building, Sustainable Development and Indigenous Peoples, December 6-8, 2000, Manila Declaration, pmbl., § 5, available at $\mathrm{http}: / / \mathrm{www}$. tebtebba.org/index.php?option=com_docman\&task=doc_download \& gid $=40 \&$ Itemid $=27$ (describing the proceedings of a conference with ninety participants from indigenous communities on five continents, all of whom signed the declaration).

56. For many years, scholars of the Iroquois Confederacy ironically touted the myth that the U.S. Constitution and American democracy itself were based partially on the Iroquois example. This trend has shifted but not without Congress weighing in. In 1988, Congress passed a resolution acknowledging the contribution of the Iroquois Confederacy of Nations to the development of the U.S. Constitution. See H.R. Con. Res. 331, 100th Cong. (1988), http://www.senate.gov/reference/resources/pdf/hconres331.pdf (last visited Oct. 29, 2010).

57. See, e.g., Colchester, supra note 29, at 3; Kenrick \& Lewis, supra note 25, at 5.

58. Kenrick \& Lewis, supra note 25 , at 9. 
privileged when considering who should have collective indigenoús rights, thus helping to allay fears of the violation of human rights of individuals who constitute part of the group..$^{59}$

At the same time, most anthropologists dealing with these matters mention international law definitional discussions but do not incorporate such definitions into an anthropological consideration. ${ }^{60}$ For example, Alan Barnard equates indigenous peoples with other legal categories and insists that this phrase should not be "in our glossary of technical terms." ${ }^{61}$ Barnard's view is a shortsighted approach to a term that, since the $1970 \mathrm{~s}$, has become embedded in theoretical discussions at all levels. In other words, the term "indigenous peoples" is not simply an "ideological construct" or "a useful tool for political persuasion," as suggested by Barnard. ${ }^{62}$ Accordingly, anthropologist Sidsel Saugestad has observed, "anthropologists writing about indigenous issues need to take heed of the codification of the concept taking place within the UN system .... If anthropologists want to reconceptualize indigenous peoples,' the point of departure must be this present use."63

This approach also considers how the success of the global indigenous movement might affect the epistemological assumptions underlying anthropological definitions of indigeneity and indigenous peoples. Anthropologists are dedicated to specificities as the crux of much of their work, but a focus on specificity should not lead anthropologists to ignore the global framework of indigenous rights, including international legal considerations now accepted and utilized in local discourse and praxis. ${ }^{64}$ As groups around the world adopt the

59. See, e.g., Klint A. Cowan, International Responsibility for Human Rights Violations by American Indian Tribes, 9 YAle HUM. RTS. \& DEV. L.J. 1, 3-4 (2006) (arguing that because the U.S. is subject to international human rights norms and American Indian tribes are a political subunit of the United States, the United States is responsible for violations of individual rights that take place on tribal lands and has an obligation to rectify such situations); Kingsbury, supra note 29, at 425-26; Luis Roniger, Citizenship in Latin America: New Works and Debates, 10 CITIZENSHIP STUD. 489, 500-02 (2006).

60. See, e.g., Bowen, supra note 52 (arguing that the emphasis on prior occupation and universality in international law's definitions is inadequate to fully satisfy considerations of equality and self-governance and proposing a more locally sensitive analytical framework instead).

61. Barnard, supra note 52, at 12.

62. Id. at 7 .

63. Sidsel Saugestad, Discussion, On the Return of the Native, 45 CURRENT ANTHROPOLOGY 263, 264 (2004).

64. Anthropologists who have confronted this crucial issue include JOANNE RAPPAPORT, INTERCUltural Utopias: PUBlic INTElleCtuAls, CUltural EXPERIMENTATION, AND Ethnic Pluralism in Columbia 64-65 (2005); ANNa Lowenhaupt TSing, Friction: AN ETHNOGRAPHY OF GLOBAL CONNECTION 205-06 (2005); Tania Murray Li, Articulating Indigenous Identity in Indonesia: Resource Politics and the Trial Slot, 42 COMP. STUD. SOC'Y AND HIST. 149, 155-57, 169-70 (2000). 
category of indigenous peoples as a claim to recognition, selfconceptualization of indigenousness has become crucial to identity formation and visions of the future. Since the $1960 \mathrm{~s}$, when an epistemological shift took hold, sociocultural anthropologists have distinguished between how people being studied explain their practices and beliefs (called "emic" or folk explanations) and how anthropologists explain those same practices and beliefs (called "etic" or analytical explanations). ${ }^{65}$ This division, though important at the time it was theorized, should be reconsidered. Peoples' use of the international discourse of indigenous rights places in question the accepted emic/etic and folk/analytical dichotomy.

Emic and etic are merely two poles of a continuum in which varying degrees of self-definition are intertwined with what were previously purely analytical concepts, such as indigeneity. Just as the imbrications of global and local reveal transnational and translocal connections between international and local identities, it is critical that anthropologists not be dismissive of indigenous as an identity simply imposed from above, but rather as a process of self-identification. This provides an opening to consider in a different way the original question posed in this article: how to honor the long-term struggles for political autonomy and self-determination of unquestionably indigenous peoples in the eyes of the world, while at the same time expanding the definitional heft of indigeneity to encompass those who have come to self-identify as indigenous more recently.

\section{PRODUCTIVE CONTRADICTIONS}

When considering a contradiction based on a presumed opposition, it is often productive to question that opposition, as proposed above regarding the emic/etic divide. James Clifford suggests reconsideration of the dichotomous "poles of autochthony (we are here and have been here forever) and diaspora (we yearn for a homeland)."66 Emphasizing the varieties of indigenous experience, he sees the displacement and migration of indigenous peoples as an "uneven, continuum of

65. See, e.g., Paul Bohannan, Justice and JUdgment AMong The Tiv 4-6 (Oxford Univ. Press reprt. 1968) (1957); ClIFFORD GEERTZ, THE INTERPRETATION OF CULTURES 330 (1973); MARVIN HaRris, THE RISE of ANTHRopological THEORY: A HiSTORY OF Theories of Culture 568-604 (Alta Mira Press updated ed. 2001) (1968); Stanley Diamond, Anthropology in Question, in REINVENTING ANTHROPOLOGY 401, $423-25$ (Dell Hymes ed., 1972); William S. Willis, Jr., Skeletons in the Anthropological Closet, in REINVENTING ANTHROPOLOGY, supra, at 121, 126-27.

66. Clifford, supra note 22 , at 205. 
attachments."67 Examples include those who have moved to urban areas, as well as people who have been expelled or forced to move from their rooted places, all of whom are "improvising new ways to be native." 68

At this point, it is useful to return to the question first posed in this article, how to justify including in the single category of indigenous peoples both those who have a clear claim to difference and those who have only recently discovered they have a claim to indigeneity under an expansive view of indigenous peoples. In considering this question, it is fruitful to imagine how such new ways of being native as the result of displacement (to cities, for example) differ from the reconstitution of indigenous identity by people like those living in the Brazilian Northeast, who assert their identity without clear evidence of indigeneity. The first form of displacement is a movement through space. The second is a movement through time, where there has been a break in identification with an indigenous past. Both involve a yearning and desire for place, distant or immediate. Anthropologist Tom Biolsi has reviewed the varieties of "indigenous political space" in the United States and described it as one in which Indian people carry "portable rights beyond reservations" (more Indians live off than on a reservation, and primarily in urban areas). He analyzes this variety in relation to the diaspora concept and considers it a form of "indigenous cosmopolitanism" because its participants do not confine themselves to indigenous territory but situate themselves both physically and culturally throughout the national space. ${ }^{69}$

Under this analysis, time can stand in for space, thus allowing for a form of temporal diasporic indigeneity. Just as one might consider the notion of diasporic indigeneity as an alternative way to inhabit "indigenous political space," a temporal diaspora might be an appropriate way to think about those who are reconstituting an indigenous identity. They base their reconstitution of identity on the presumed settlement in a particular place in centuries past. The "new" tribes in Brazil's Northeast imagine their indigenous roots in a time before prior generations were decimated by disease, assimilationist policies, and Catholic Church resettlement of surviving members of distinct tribes to missions, where they were put to work on the Church's land. The term remanescentes (translated variously as remnants, remainders, or descendants) was used to describe newly reconstituted

67. Id. at 215 .

68. Id. at 198.

69. Thomas Biolsi, Imagined Geographies: Sovereignty, Indigenous Space, and American Indian Struggle, 32 AM. ETHNOLOGIST 239, 248-49 (2005). 
indigenous groups in Brazil from the beginning of the renewal process. ${ }^{70}$ By recognizing these groups and providing them with land and rights as Indians, the Brazilian government is recognizing a previously unacknowledged link to a historical crime committed by the colonial authorities, the state, and the Catholic Church. This decision, made by both the state and the church, ${ }^{71}$ represents the recognition that a "claim to indigeneity is a claim to justice based not simply on historical priority but a sense of historical injustice"; such indigenous identities are "dynamic and processual and rooted in contemporary social relations, even as [people] invoke an historical perspective to make sense of who they are."72 After all, it may be unjust, from a historical perspective, if the descendants of those who had their identity stolen are denied rights while those who happened to live beyond the reach of the colonial powers are unquestionably recognized as indigenous.

Brazil's solution to this potential injustice came about as an unintended consequence of the Indian Statute of $1973 .{ }^{73}$ Brazil's military government, which ruled from 1964 to 1985 , enacted this law to regularize property rights in the Amazon region to protect the country's outer reaches from invasion by foreigners. The intention of the statute was to remove Indians from areas that could be developed and to place them in legally demarcated territories called reservas. Although this led to the disruption of many of the indigenous peoples in the Amazon, it also "broke political ground for Indians to stake their claims," based on government recognition of the demarcated territories as dedicated to the Indians resettled there. ${ }^{74}$ As it turned out, that law not only helped Amazonian Indians in their demands for demarcation of lands and provision of resources, it also inadvertently provided an opening for

70. José Maurício ARruti, Mocambo: ANTropologia E História do Processo dE FORMAÇÃO QUILOMBOLA 80 (2005).

71. In 1971, Bishops' Councils of the Catholic Church in the Amazon and the Northeast issued statements condemning historical and continuing dispossession of indigenous peoples in Brazil. FRENCH, supra note 1, at 36-37. The following year, the church created the Indigenist Missionary Council (CIMI), which is still active today supporting groups throughout the country. Id. at 37.

72. Andrew Canessa, The Past Is Not Another Country: Exploring Indigenous Histories in Bolivia, 19 HIST. \& ANTHROPOLOGY 353, 355, 367 (2008).

73. FRENCH, supra note 1, at 25-26.

74. Seth Garfield, Where the Earth Touches the Sky: The Xavante Indians' Struggle for Land in Brazil, 1951-1979, 80 HISP. AM. HIST. REV. 537, 546 (2000). Article 23 of the Indian Statute of 1973 establishes that "the lands occupied by them in accordance with their tribal usage, customs and tradition, including territories where they carry on activities essential for their subsistence or that are of economic usefulness" constitute territory of the Indians. Estatuto do Índio, Lei No. 6001, de 19 de Dezembro de 1973, DIÁRIO OFICIAL DA UNIĀO [D.O.U.] de 21.12.1973 (Braz.), available at http://www.funai.gov.br/quem/legislacao/estatuto_indio.html. 
previously unrecognized descendants of "reduced" Indian mission communities to demand their newly conceived rights as Indians and not simply remanescentes.

In 1973, for the first time, the term "Indian" was legally defined in Article 3 of the Indian Statute as follows: "Indian or forest dweller is every individual of Pre-columbian origin and ancestry who identifies himself and is identified as belonging to an ethnic group whose cultural characteristics distinguish him from the national society." 75

Previously, indigenous people in Brazil were referred to as forest dwellers (silvicolas), with the assumption that there was no need to set out a definition since the only indigenous groups were isolated Amazonian tribes, each with its own language and cultural practices. Although the new definition in Article 3 codified an assimilationist perspective in following Article 4, ${ }^{76}$ it also allowed for those of "preColumbian origin and ancestry" to identify themselves as Indian, so long as they were "identified as belonging to an ethnic group whose cultural characteristics distinguish [them] from the national society." 77 Within a decade of its enactment, Article 3 of the statute was being used independently of Article 4, which defined stages of acculturation and had taken on a life of its own. In practice, the origin and ancestry clause of Article 4 has been effectively broadened, in part because of the universal Brazilian belief that all rural people have some indigenous ancestry, along with African and Portuguese (and Dutch in the Northeast). ${ }^{78}$ Unlike the United States, African ancestry of an individual does not trump other ancestries, thus allowing each person certain flexibility in ethnoracial self-identification. In fact, the statute does not mention racial characteristics as a condition of Indian categorization. Paradoxically, in light of the spate of recognitions of peoples who could be classified as "integrated" under Article 4, it is precisely that article, with its potential and legally permissible transformation of ethnic Indians into non-Indians, which requires the origin and ancestry clause of Article 3 to be virtually ignored as a racial requirement. If some people can cease being Indians, there is no impediment for others to become Indians. In the twenty-five years since redemocratization, the assimilationist perspective has been rejected,

75. FRENCH, supra note 1 , at 66-67.

76. Article 4 contains three classifications of indigenous communities: isolated, integrating, and integrated, reflecting the policy of the government at the time, which was to encourage, and even force, assimilation into the general population. If found to be integrated, the government could declare an entire community integrated into Brazilian society at the request of its members-this has never been requested. Id. at 198 n.42.

77. Id. at 66-67.

78. Id. at 67,69 . 
and indigenous people who move to the city are no longer stripped of their legal identities as Indians..$^{79}$ With the newly recognized tribes, the overall indigenous population has increased dramatically.

1. Illustrating the power of definition (or lack thereof), in the case of Brazil, adding a definition performed the same function as excluding a definition in the Declaration on an international level. Thus, with Brazil as one example of a broadened definition of indigenous peoples, the undefined term in the Declaration permits a range of groups existing along a spatial-temporal continuum to claim indigenous rights. ${ }^{80}$ In other words, the newly recognized, previously assimilated, northeastern Brazilian tribes; peoples in Africa and Asia who would not otherwise meet a definition that requires European colonization or "firstness" in time; and those, such as the Roma or Gypsies, who do not have a homeland (even an imagined one), can all claim indigeneity.

\section{CONCLUSION}

So long as there is no restrictive definition, a group could be recognized as indigenous on an international level because indigeneity should be "sufficiently flexible to accommodate a range of justifications" and should not be about a list of characteristics or "firstness." 81 By looking at indigenous in terms of justifications, rather than characteristics, it might be possible to recognize as indigenous "groups [that] draw upon the international concept of 'indigenous peoples' in constructing their own identities." 82 In this way, groups "whose selfconcept might not have centered on prior possession may come to identify themselves as indigenous peoples with experiences and

79. The 1988 Constitution, the first democratically promulgated constitution in decades, expanded rights of, and protections for, indigenous peoples, but left the 1973 definition in effect.

80. Of course, one should not take the continuum metaphor too literally. In each case, a group's history is marked by varying relationships to a particular space and/or identifications. I would like to thank environmental and labor historian Tom Rogers for making this observation.

81. Kingsbury, supra note 29 , at 418 . For example, Kingsbury proposes an approach that "treat[s] historical continuity as an indicator rather than a requirement," thus emphasizing a "commonality of experiences, concerns and contributions made by groups in many different regions." Id. at 457 . This would "establish a unity that is not dependent on the universal presence of historical continuity," which traditional analyses have, to date, almost always considered a justification intrinsic to indigeneity. Id. He argues that such a justification "does not accurately capture identities and outlooks in some regions not structured by waves of recent invasion and migration," specifically India and China. Id. at 456.

82. Id. at 450 . 
worldviews shared with other indigenous peoples." 83 Such an approach is reinforced by the successful assertion by representatives from Africa and Asia of their status as indigenous in the negotiations leading up to the adoption of the Declaration and by the recognition of reconstituted Indian tribes in Brazil.

Firstness in time and place is less important than the common conditions of people who consider themselves to be indigenous and claim rights as such. Although a common reaction when discussing this issue is incredulity that a legal document could lack a definitional section, upon further reflection, it becomes apparent that a lack of definition can serve as a suture, an impetus for common struggle. Further, the success of peoples currently self-identifying as indigenous, in being accepted by the international community, should be more fully incorporated into anthropological analyses of identity formation, especially as this success is connected to supranational and state entities and practices. In fact, the decision to exclude a definition from the Declaration brings that document closer to an anthropological perspective on cultural practices and identity formation. ${ }^{84}$ Working to understand how particular indigenous peoples incorporate their new global indigenous identity will enhance both international legal and anthropological scholarship and allow those whose interests are most at stake to be given opportunities to participate in definitional discussions tied to rights and resources.

83. Id.

84. See Jan Hoffman French, Making Identity: Law, Memory, and Race in Comparative Perspective in RACE, Roots \& RELATIONS: NATIVE AND AFRICAN AMERICANS 248 (Terry Straus ed., 2005) (comparing the use of blood quantum for determining Indian identity in the United States and the use of cultural indicia and self-identification in Brazil). 
